\title{
Start-up, growth and internationalisation of entrepreneurial ventures by the use of service families.
}

\begin{abstract}
his article uses a single case study methodology that draws from the process-based life cycle models of (a) product development (b) product family development and (c) new venture development. It analyses e-Pay Asia's efforts to pioneer an electronic prepaid airtime reload delivery system and subsequently develop it into a comprehensive payment service family. This research resulted in the identification of close linkages between new services development and service family extension, especially as they regard internationalisation and new venture development. Both new service development/extension and internationalisation contributed to the development and rapid growth of the case company, thereby confirming the Uppsala model of internationalisation.
\end{abstract}

Keyword: Entrepreneurial ventures; Growth; Internationalisation; Service families; Start-up. 